\title{
Red-eared terrapin farms and conservation
}

\author{
Clifford Warwick
}

Taking animals from the wild to supply the pet trade is often a cause for concern, both on welfare and conservation grounds. The redeared terrapin Pseudemys scripta elegans is just one subspecies involved, and its survival in certain parts of its range is under threat as a result.

Red-eared terrapins (called turtles or sliders in the USA) are a primarily aquatic, freshwater species. They inhabit ponds, slow-running rivers, bayous (where rivers meet multiple diversions and form small streams) and swamplands from Jackson County in the south-east to Texas and north to Illinois (Figure 1).

They are active throughout the warmer months, and their diet includes small fish, insects, amphibians, snails, carrion and pondweeds. The

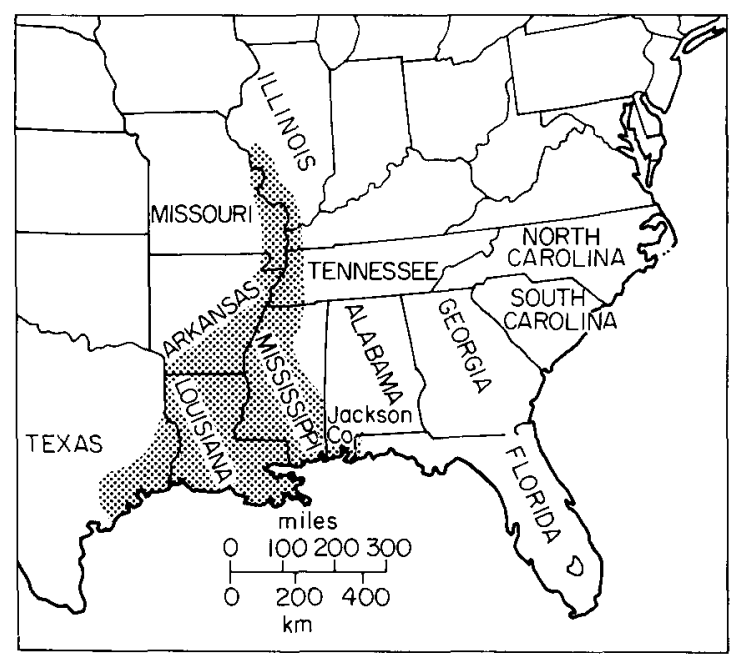

Figure 1. Distribution of red-eared terrapins Pseudemys scripta elegans in the USA (Behler and King, 1979).

Red-eared terrapin farms and conservation young are mainly carnivorous, but a dietary shift towards vegetation occurs as they increase in size (Hart, 1983). They often spend several hours a day basking on logs, tree roots and river banks. At night, or during the brief but harsh winters, particularly at the most northern end of their range, they retreat into dense sediment or into mud banks. The young are heavily preyed upon by large fish, birds, small mammals and young alligators. The adults, which may attain carapace lengths of $20 \mathrm{~cm}$ for the males and $30 \mathrm{~cm}$ for the females, are preyed upon by large alligators, racoons and man (Dr P. C. H. Pritchard, pers. comm., farm management, and pers. obs.).

In 1984 I visited four terrapin breeding farms in Louisiana to collect information for an investigation into the international trade in this subspecies (Figure 2). Care was taken to select a

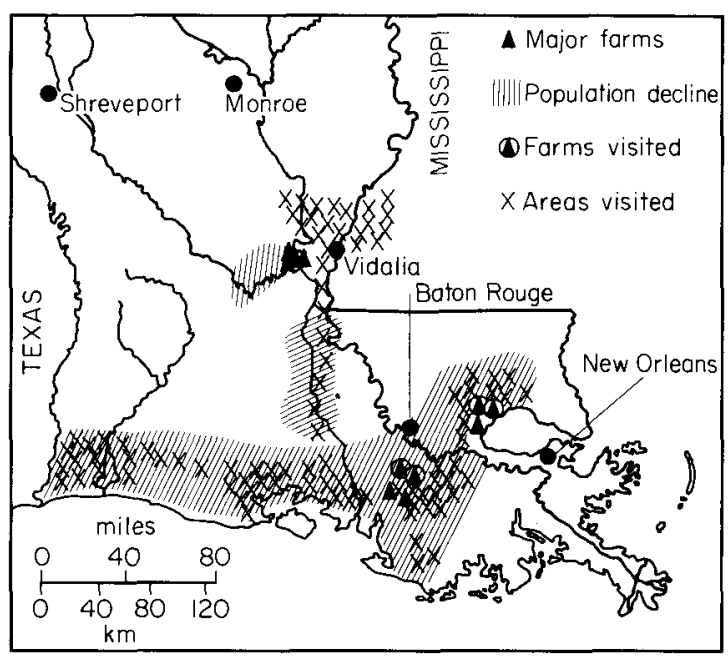

Figure 2. The area covered by the red-eared terrapin survey and the distribution of major terrapin farms. 
representative range of farms in size, structure and management. Farm managers requested confidentiality and for this reason I identify them by letters $A-D$. Farms $A$ and $B$ are among the largest in the state, employing full-time permanent staff, as well as casual labour during the egg-collecting seasons. Farm $C$ is a full-time, purely family concern, and Farm $D$ has a parttime supervisor and farms terrapins to supplement other income.

From about 1950 turtle dealers set up throughout most of the southern states of the US, where they could collect terrapins from the wild. However, a reliable catch could not be guaranteed and commercial farming began around 1957. Breeding stocks were taken from wild populations, but it was believed these would recover as the farmers built up captive stocks of breeding turtles. By 1960 more than 150 farms were in operation, according to farm managers I questioned. This gives some idea of the quantity initially collected from wild populations for farm breeding stock.

In 1975 the Food and Drug Administration banned the trade in hatchlings within the USA, following studies that concluded that these reptiles were a significant cause of salmonellosis in humans (Federal Register, 1975). An annual market of some 10,000,000 animals was lost and
Table 1. Approximate number of adult red-eared terrapins forming captive breeding stocks

$\begin{array}{lr}\text { Farm A } & 70,000 \text { distributed between } 5 \text { ponds } \\ \text { Farm B } & 20,000 \text { distributed between } 2 \text { ponds } \\ \text { Farm C } & 7000 \text { distributed between } 2 \text { ponds } \\ \text { Farm D } & 12,000 \text { in } 1 \text { pond }\end{array}$

Total $=109,000$

Figures supplied by farm management.

Table 2. Approximate number of adult red-eared terrapins taken from the wild annually by four farms visited

\begin{tabular}{lllr}
\hline Farm A & 4000 & Farm C & 3000 \\
Farm B & 2000 & Farm D & 400 \\
Total $=9400$ & & &
\end{tabular}

Figures supplied by farm management.

as a result only about 50 farms were left in business. Since that time the terrapin farmers' union, the National Turtle Farmers' and Shippers' Association (NTFSA), has sought to overturn the ban with petitions of proposals for packaging their 'produce' in containers where, in theory, they will remain salmonella-free. If the proposals were accepted the cleaned terrapins would be sent to factories where they would be hermetically sealed in clear plastic containers during transport, storage and display. Once sealed, the 'plastic bubbles', as they are referred to, would not be opened until the terrapins

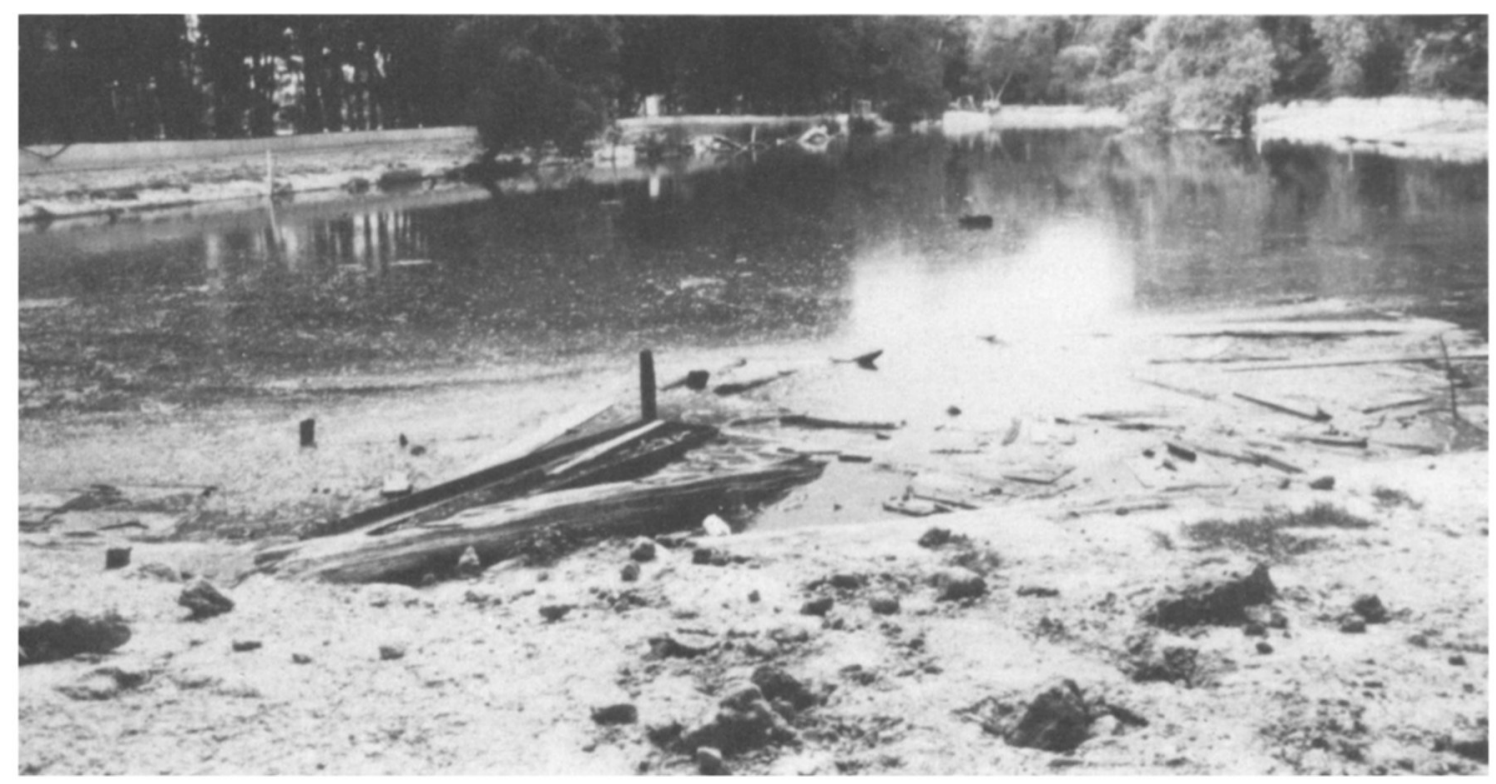

A debris-strewn farm pond containing 12,000-13,000 adult breeding terrapins ( $C$. Warwick). 
Right: The 'drying-out' box, where hatchlings are placed ready for transportation

(C. Warwick).

Below: A section of an incubation room. This farm held 230,000 eggs and hatchlings in two rooms. One of the rooms may be maintained at $15-16^{\circ} \mathrm{C}$ for up to one year to retard development of embryos when demand is low (C. Warwick).

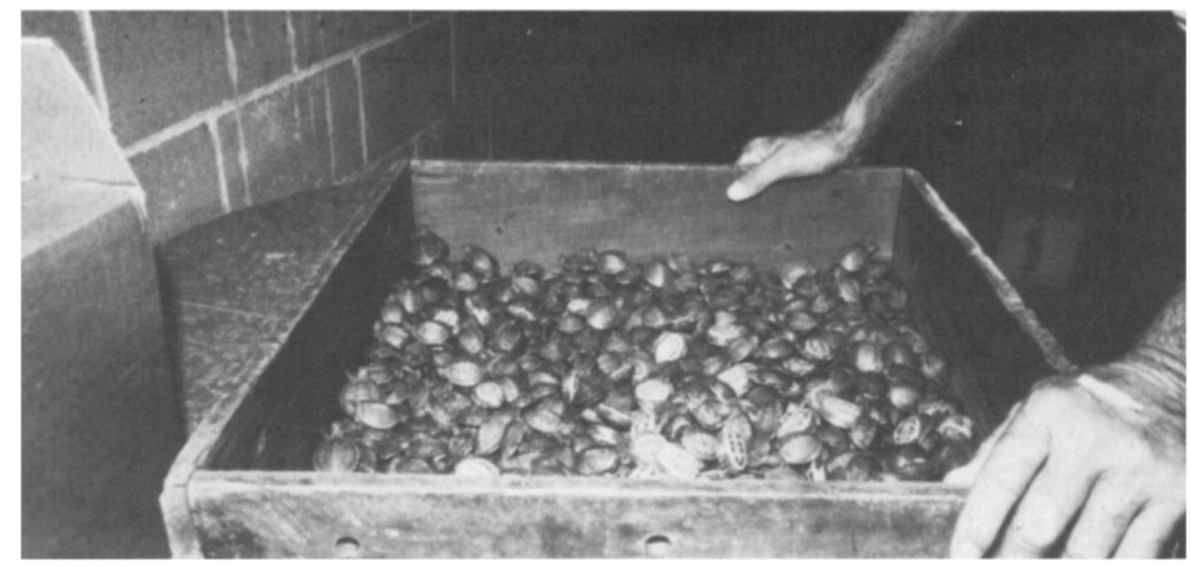

reached private homes, where they would be kept in a chemical solution to prevent then becoming contaminated with salmonella and related bacteria. Unsold terrapins would remain in their individual packages until they died.

Unfortunately, the farmers' original plan to conserve wild populations proved ineffective. As an example, the four farms I visited, which between them held 109,000 breeding individuals (Table 1), take approximately 9400 adults from the wild annually. These are to replace those that die during or shortly after winter and in expectation that the ban will be overturned. The high mortality rate may be due largely to the fact that the ponds are mainly artificial, being only 1.2$4.5 \mathrm{~m}$ deep, and lack deep sediment to insulate the terrapins from the cold. Furthermore, adults may have their food supply restricted in order to reduce the number of eggs being produced when demand for pets is low. This causes a substantial drain on the body fat reserves necessary to sustain them through hibernation. If this kind of mortality rate occurs in all the 50 farms, there could be 100,000 or more wild adults captured for the trade annually (Table 2).

One of the most worrying aspects of the campaign to get the ban lifted is that if it were successful most farmers agree that they would need to increase their breeding stocks threefold. Furthermore, the farms that closed when the ban was introduced would almost certainly reopen, taking additional stock straight from the wild.

There seems to be no doubt that commercial Red-eared terrapin farms and conservation

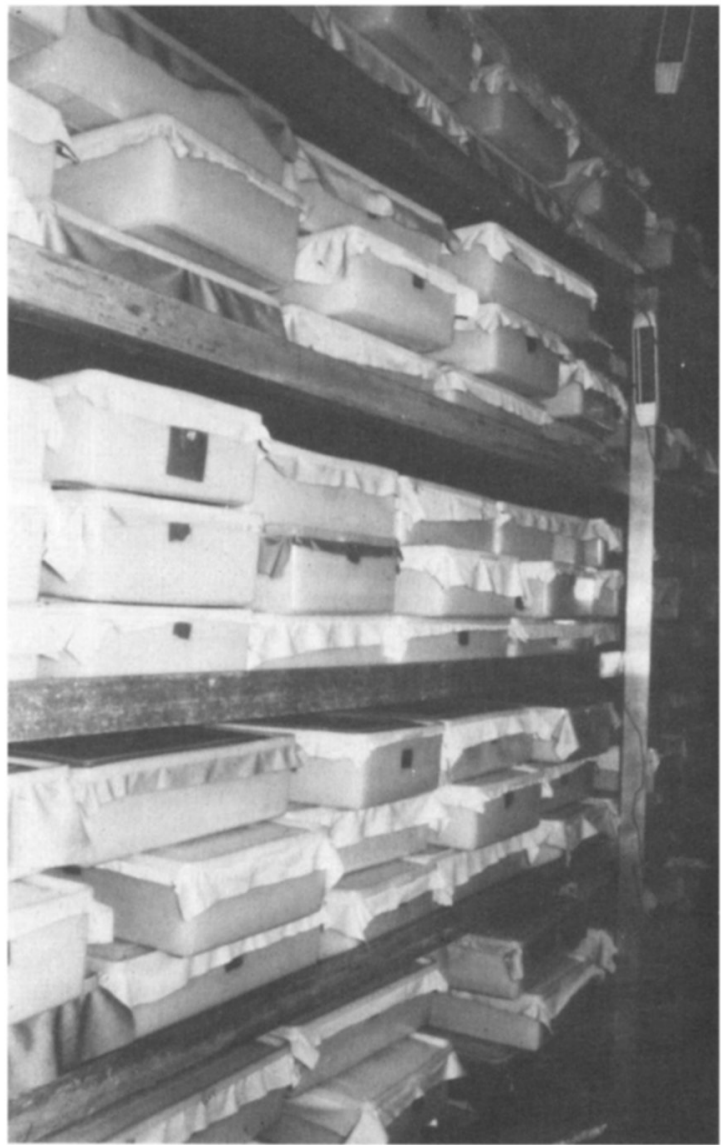

farming has already severely depleted wild stocks of at least some populations. Both the local people and the farmers state that at one time red-eared terrapins were very common in the 
Table 3. Export figures of red-eared terrapins during 1983 via New Orleans airport

\begin{tabular}{lr}
\hline Destination & Quantity \\
\hline Japan & 860,000 \\
France & 280,000 \\
Italy & 132,000 \\
Hong Kong & 111,000 \\
Spain & 95,000 \\
England & 58,000 \\
Belgium & 56,000 \\
West Germany & 54,000 \\
Mexico & 43,000 \\
Netherlands & 30,000 \\
Total = 1,719,000 & \\
\hline
\end{tabular}

Figures supplied by US Law Enforcement Division, Law Office.

southern areas, particularly throughout Louisiana. In the early days of farming it was possible for farms to catch 4000-5000 adults each year. Now they claim that even baited traps return only 400-500 each year at best. The rest of those caught for the farmers' ponds are supplied by terrapin hunters operating further north in Arkansas, where these reptiles are apparently still common.

I made an extensive 42-mile search in paddle boats of seemingly ideal terrapin territory in southern Louisiana and saw only about six terrapins each day. By contrast, during my stay I travelled north to Vidalia, in central Louisiana, where there are wildlife refuges and private parks protected by alligator and rattlesnake hunters from outside exploitation. No one takes any interest in terrapins there and I saw 80, 120 and 180 individuals on three consecutive days basking in an area of approximately 5 acres ( 2 ha) of swampland.

Until recently, export and import records of animals that were not on the endangered species list, which includes red-eared terrapins, had not been regularly maintained. Since 1982, however, the US Law Enforcement Division has sought to list the exporter, consignment and destination for all wildlife traffic. Although consignments are shipped through other airports, the Law Office only had data relating to turtles exported via New Orleans airport (Table 3). Export figures given by the farming industry refer to the total annual production and are much higher. It claims that 240 between 4,000,000 and 5,000,000 terrapin hatchlings are exported annually; about 50 per cent of these are exported through New Orleans. In fact, the four farms visited alone claim to produce approximately $1,220,000$ each year. About 55 per cent of these go to Europe, 44 per cent to the Far East, and 1 per cent to smaller markets, such as Venezuela.

The farmers are careless about the welfare of the terrapins. When asked how they justify keeping adults and hatchlings in cramped unnatural conditions until they are sold or die, one farmer said that he would prefer to talk about something else, because that is the sort of question that could put him out of business.

In August 1985 the US Society for the Study of Amphibians and Reptiles endorsed a resolution opposing the commercial exploitation of turtles for the pet trade. In a letter to the US Food and Drug Administration, the Society expressed growing concern about the depletion of wild stocks and the export of salmonella to other nations. It also pointed out that it was not in concert with the packaging proposals offered by the pet turtle industry on the grounds that they were inhumane and failed to address conservation concerns as well as epidemiological problems.

The campaign to stop exporting the turtles for the pet trade is being fought on human health, humane and conservation grounds. In June 1984 I began a survey in the British Isles with the objective of accumulating information about the survival of the species in captivity and its suitability as a pet. A campaign against the terrapin trade in the UK is being organized by the People's Trust for Endangered Species, with myself as co-ordinator.

\section{References}

Behler, J.L. and King, F.W. 1979. Audubon Society Field Guide to North American Reptiles and Amphibians. Alfred A. Knopf, New York.

Federal Register, 1975. Ban on the sale and distribution of small turtles, part 1240-control of communicable diseases. 23 May, 40, 101. 22.543-22.546.

Hart. D.R. 1983. Dietary and habitat shift with size of redeared turtles (Pseudemys scripta) in a southern Louisiana population.

Clifford Warwick. People's Trust for Endangered Species. Hamble House, Meadrow. Godalming. Surrey GU7 3JX. UK.

Oryx Vol 20 No 4. October 1986 